\title{
Rheological and sensory properties and aroma compounds formed during ripening of soft brined cheese made from camel milk
}

Hailu, Yonas; Hansen, Egon Bech; Seifu, Eyassu; Eshetu, Mitiku; Petersen, Mikael Agerlin; Lametsch, Rene; Rattray, Fergal; Ipsen, Richard

Published in:

International Dairy Journal

Link to article, DOI:

10.1016/j.idairyj.2018.01.007

Publication date:

2018

Document Version

Peer reviewed version

Link back to DTU Orbit

Citation (APA):

Hailu, Y., Hansen, E. B., Seifu, E., Eshetu, M., Petersen, M. A., Lametsch, R., Rattray, F., \& Ipsen, R. (2018). Rheological and sensory properties and aroma compounds formed during ripening of soft brined cheese made from camel milk. International Dairy Journal, 81, 122-130. https://doi.org/10.1016/j.idairyj.2018.01.007

\section{General rights}

Copyright and moral rights for the publications made accessible in the public portal are retained by the authors and/or other copyright owners and it is a condition of accessing publications that users recognise and abide by the legal requirements associated with these rights.

- Users may download and print one copy of any publication from the public portal for the purpose of private study or research.

- You may not further distribute the material or use it for any profit-making activity or commercial gain

- You may freely distribute the URL identifying the publication in the public portal 


\section{Accepted Manuscript}

Rheological and sensory properties and aroma compounds formed during ripening of soft brined cheese made from camel milk

Yonas Hailu, Egon Bech Hansen, Eyssu Seifu, Mitiku Eshetu, Mikael Agerlin

Petersen, Rene Lametsch, Fergal Rattray, Richard Ipsen

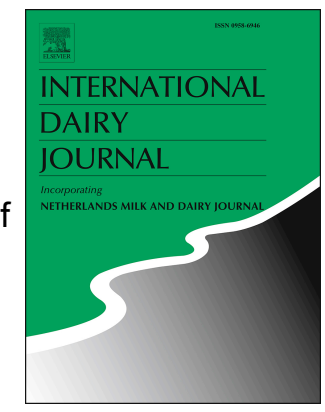

PII:

S0958-6946(18)30031-1

DOI:

10.1016/j.idairyj.2018.01.007

Reference: INDA 4267

To appear in: International Dairy Journal

Received Date: 13 November 2017

Revised Date: 21 January 2018

Accepted Date: 22 January 2018

Please cite this article as: Hailu, Y., Hansen, E.B., Seifu, E., Eshetu, M., Petersen, M.A., Lametsch, R., Rattray, F., Ipsen, R., Rheological and sensory properties and aroma compounds formed during ripening of soft brined cheese made from camel milk, International Dairy Journal (2018), doi: 10.1016/ j.idairyj.2018.01.007.

This is a PDF file of an unedited manuscript that has been accepted for publication. As a service to our customers we are providing this early version of the manuscript. The manuscript will undergo copyediting, typesetting, and review of the resulting proof before it is published in its final form. Please note that during the production process errors may be discovered which could affect the content, and all legal disclaimers that apply to the journal pertain. 
1 Rheological and sensory properties and aroma compounds formed during ripening of soft brined cheese made from camel milk

3

4

5

6

7 Yonas Hailu ${ }^{\mathrm{a}, \mathrm{b}^{*}}$, Egon Bech Hansen $^{\mathrm{c}}$, Eyssu Seifu ${ }^{\mathrm{d}}$, Mitiku Eshetu ${ }^{\mathrm{b}}$, Mikael Agerlin Petersen ${ }^{\mathrm{a}}$, Rene 8 Lametsch $^{\mathrm{a}}$, Fergal Rattray ${ }^{\mathrm{a}}$, Richard Ipsen ${ }^{\mathrm{a}}$

9

${ }^{a}$ University of Copenhagen, Department of Food Science, Rolighedsvej 30, 1958 Frederiksberg C,

\section{Denmark}

${ }^{b}$ Haramaya University, School of Animal and Range Sciences, P.O. Box: 138, Dire Dawa, Ethiopia

${ }^{c}$ Technical University of Denmark, National Food Institute, 2860-Sфborg, Denmark

${ }^{d}$ Department of Food Science and Technology, Botswana University of Agriculture and Natural

Resources, Private Bag 0027, Botswana
9

0

1

2

3 *Corresponding author. Tel.: +251911705851

E-mail address: yonashailu421@gmail.com (Y. Hailu) 
25

26

27

28

29

30

31

32

33

34

35

36

37

38

39

40

\section{ABSTRACT}

Protein degradation, rheological properties, sensory properties and the aroma profile of soft brined cheese made from camel milk using two levels of coagulant (camel chymosin) [55 and 85

International Milk Clotting Units (IMCU) $\mathrm{L}^{-1}$ ] and two levels of brine $(2 \%$ or $5 \% \mathrm{NaCl}$, w/w) were investigated over a ripening period of $60 \mathrm{~d}$. Casein degradation in soft brined camel milk cheese significantly $(p<0.05)$ increased during ripening and with increase of coagulant level. Young's modulus and stress at fracture significantly $(p<0.05)$ increased with increasing level of salt in moisture in the cheese during ripening. However, cheese made with $85 \mathrm{IMCU} \mathrm{L}^{-1}$ coagulant resulted in softening of cheese texture and higher salt uptake. Using descriptive sensory analysis, the experimental cheeses were described as salty, sour and firm. The volatile aroma compounds formed in soft ripened camel milk cheese are affected by ripening time, and coagulant and $\mathrm{NaCl}$ levels. 


\section{Introduction}

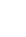

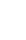

Production of cheese from camel milk has been difficult due to the lack of available coagulants able to specifically cleave camel $\kappa$-casein. With the availability of camel chymosin as coagulant (Kappeler et al., 2006) this is now changing and a few reports have been published recently on soft cheeses from camel milk (Benkerroum, Dehhaoui, El Fayq, \& Tlaiha, 2011; Hailu, Seifu, \&Yilma, 2014; Konuspayeva et al., 2016). The texture and appearance of cheese is as important as the flavour and it is one of the first properties that consumers use to identify and judge specific cheese varieties (Lawrence, Creamer, \& Gilles, 1987). Cheese texture measurement can provide important information for new product development, product quality monitoring and about the structure of the product itself (i.e., elastic deformation, plastic deformation and hardness) (Essex, 1969). The quality of brined cheeses is affected by the duration of ripening due to proteolysis and lipolysis as well as changes in cheese appearance (Pappas, Kondyli, Voutsinas, \& Mallatou, 1996).

Consumer studies (sensory evaluation) for food products are one of the central points for success in new food product development (Drake, 2007). Addition of $\mathrm{NaCl}$ to the cheese is necessary for the flavour and texture development of cheeses and it is also one of the sensory attributes perceived as a basic flavour (Guinee, 2004; Guinee \& Fox, 2004). Firmness of brined cheese made from bovine milk increased with increasing the concentration of $\mathrm{NaCl}$ in the brine, salting time, and salt in moisture content of the cheese (Guinee \& Fox, 2004; Prasad \& Alvarez, 1999). Salt affects the rheological properties of cheese by enhancing casein aggregation or hydration, causing cheese hardness and brittleness to increase with increase in $\mathrm{NaCl}$ concentration (Guinee \& Fox, 2004; Pastorino, Hansen, \& McMahon, 2003). The maturation of cheese involves complex biochemical changes due to microbiological and enzymatic processes that provide 
different flavour characteristics (McSweeney, 2004; McSweeney \& Sousa, 2000) and variations in texture (McSweeney, 2004). Biochemical changes such as lipolysis, proteolysis, metabolism of residual lactose, lactate, citrate, fatty acids and amino acids (McSweeney, 2004) result in development of different flavour compounds in cheese during ripening (McSweeney \& Sousa, 2000).

To date, there are no reports on the effect of $\mathrm{NaCl}$ and coagulant (camel chymosin) concentration on the casein degradation, rheology, sensory quality and aroma profile of soft brined cheese made from camel milk. Therefore, the aim of this study was to investigate these properties at two different levels of $\mathrm{NaCl}(2 \%$ and $5 \%, \mathrm{w} / \mathrm{w})$ and coagulant $\left(55\right.$ and $\left.85 \mathrm{IMCU} \mathrm{L}^{-1}\right)$ to better understand the structural changes and characterise the product over $60 \mathrm{~d}$ of ripening.

\section{Materials and methods}

\subsection{Materials}

Pooled camel milk samples were collected from 15 to 20 camels owned by pastoralists in the Erer Valley, Eastern Ethiopia, and transported in an icebox $\left(4-5^{\circ} \mathrm{C}\right)$ to Haramaya University for cheese making. Camel chymosin (Chy-Max ${ }^{\circledR}$ M; EC 3.4 23.4) with a strength of 1000 International Milk Clotting Units (IMCU) $\mathrm{mL}^{-1}$ and freeze-dried starter culture (i.e., Streptococcus thermophilus STI-12) were obtained from Chr. Hansen, Hørsholm, Denmark. All chemicals used were analytical grade from Sigma Aldrich, Mannheim, Germany.

\subsection{Experimental design}


The rheological, sensory properties and aroma profiles of the cheese samples were evaluated over a ripening period of $60 \mathrm{~d}$ using a $2 \times 2 \times 3$ factorial arrangement with completely randomised design. Four soft cheeses were made using coagulant concentrations of 55 or $85 \mathrm{IMCU} \mathrm{L}^{-1}$ and $\mathrm{NaCl}$ levels of $2 \%$ or $5 \%(\mathrm{w} / \mathrm{w})$ in solutions and sampled on 0,30 and $60 \mathrm{~d}$ of ripening. Proteolysis was studied on $0,20,40$ and $60 \mathrm{~d}$ of ripening (where $0 \mathrm{~d}$ is $24 \mathrm{~h}$ after manufacturing and immediately before the drained curd is transferred into the brine). The cheeses were made at Haramaya University, Ethiopia, and portions of each cheese samples were vacuum sealed in food grade plastic and frozen at $-20^{\circ} \mathrm{C}$ for volatiles analysis. The experiment was performed in duplicate.

\subsection{Cheese manufacturing}

An Armfield FT20 (Armfield Ltd., Ringwood, Hampshire, UK) cheese vat was used for cheese making. Ten litres of pooled camel milk was pasteurised at $63{ }^{\circ} \mathrm{C}$ for $30 \mathrm{~min}$ and $0.02 \%$ $\mathrm{CaCl}_{2}$ was added. After 20 min, the starter culture (Str. thermophilus STI-12) at a level of $75 \mathrm{U}$ $1000 \mathrm{~L}^{-1}$ was added to the milk and acidified for $15-20 \mathrm{~min}$ at $36-38{ }^{\circ} \mathrm{C}$. The coagulant ChyMax ${ }^{\circledR} \mathrm{M}$ was then added at a level of $55 \mathrm{IMCU} \mathrm{L}^{-1}$ or $85 \mathrm{IMCU} \mathrm{L}^{-1}$ and the milk was kept for $2 \mathrm{~h}$ at $36-38{ }^{\circ} \mathrm{C}$. The cheese curd was sliced with a knife into $2 \mathrm{~cm}$ cubes and held for $10 \mathrm{~min}$ to facilitate whey drainage. After that the cheese curd was transferred to the mould and inverted twice every 2 h. The whey drainage in the mould was performed at $18-20^{\circ} \mathrm{C}$ overnight and the curd was placed into a respective brine concentration of $2 \%$ or $5 \% \mathrm{NaCl}(\mathrm{w} / \mathrm{w})$. The mean $\mathrm{pH}$ of cheese curd during curd cutting and drainage steps of cheese manufacturing was $5.90 \pm 0.10$ and $5.79 \pm 0.10$, respectively. Similar volumes of cheese were brined in uniformly sized air tight transparent plastic 
cans at $4-5{ }^{\circ} \mathrm{C}$. The $\mathrm{pH}$ of the brine was adjusted using glucono- $\delta$-lactone (Sigma-Aldrich) to the $\mathrm{pH}$ value of each cheese (i.e., 4.7-4.9).

\subsection{Physicochemical properties}

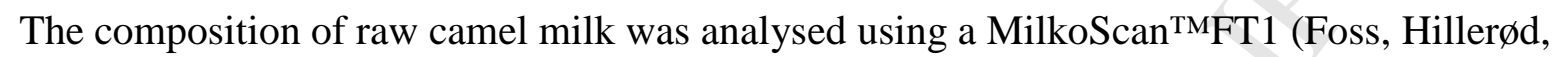
Denmark). The $\mathrm{pH}$ of cheese was measured by puncturing grated cheese with a calibrated $\mathrm{pH}$ meter electrode according to Ardö and Polychroniadou (1999). Total solids and ash content of cheese samples were measured using gravimetric methods. Fat content of the cheese samples was measured using the Gerber method (AOAC, 1995). NaCl content was determined using an automated potentiometric end point titrator (DL50, Mettler-Toledo A7S, Glostrup, Denmark) (ISO5943:IDF88, 2006). The protein content of the cheese was determined using Kjeldahl method (AOAC, 1995). Proximate analysis of the cheese samples was performed in duplicate.

\subsection{Proteolysis study}

\subsubsection{Soluble nitrogen frication}

Citrate dispersion and soluble nitrogen fractions, i.e., $\mathrm{pH} 4.4$ soluble nitrogen ( $\mathrm{pH} 4.4 \mathrm{SN}$ ), $12 \%$ trichloroacetic acid soluble nitrogen (12\% TCA-SN) and 5\% phosphotungstic acid soluble nitrogen (5\% PTA-SN), were prepared according to Ardö and Polychroniadou (1999). Grated cheese $(12.5 \mathrm{~g})$ was mixed with $50 \mathrm{~mL}$ of warm $\left(40-50{ }^{\circ} \mathrm{C}\right) 0.5 \mathrm{M}$ trisodium citrate solution in a 100 $\mathrm{mL}$ beaker and stirred for $60 \mathrm{~min}$ until the cheese was completely dispersed. The warm cheese citrate dispersion was then cooled to room temperature and adjusted to $250 \mathrm{~mL}$ with distilled water and the soluble nitrogen fractions (i.e., $\mathrm{pH} 4.4 \mathrm{SN}, 12 \%$ TCA-SN and 5\% PTA-SN) were prepared 
and analysed to evaluate proteolysis in the cheese accordingly. The protein content of the cheeses were determined using the Kjeldahl method (AOAC, 1995).

\subsubsection{Sodium dodecylsulphate polyacrylamide gel electrophoresis}

Protein degradation analysis was performed using sodium dodecylsulphate polyacrylamide gel electrophoresis (SDS-PAGE). The cheese sample for analysis was prepared by dissolving $1.2 \mathrm{~g}$ of cheese in $25 \mathrm{~mL}$ of $8 \mathrm{M}$ urea at $\mathrm{pH}$ of 8.5 and homogenising for 2 min using a T25 digital Ultra$\operatorname{Turrax}^{\circledR}\left(\mathrm{IKA}^{\circledR}-\right.$ Werke GmbH and Co.KG, Staufen im Breisgau, Germany) and the cheese extract was incubated for $2 \mathrm{~h}$ at $37^{\circ} \mathrm{C}$ to complete solubilisation of casein. The completely solubilised casein in urea was centrifuged at $10,000 \times g$ for $30 \mathrm{~min}$ at $4{ }^{\circ} \mathrm{C}$ and filtered using $11 \mu \mathrm{m}$ pore size filter paper to remove fat and other insoluble matter. The filtrate solutions were dialysed overnight using dialysis membranes of 6-8 kDa cutoff (Spectra/Por ${ }^{\circledR}$ Membrane Dialysis Products, Spectrum Labs, Torrence, CA, USA) and the dialysed sample was lyophilised (CHRIST Beta 1 - 8 LD plus, Göttingen, Germany). The lyophilised protein sample was diluted 1:1 with 2× Laemmli sample buffer (Bio-Rad Laboratories Ltd., Hercules, CA, USA) and heated for $5 \mathrm{~min}$ at $95{ }^{\circ} \mathrm{C}$ to denature the protein (Park \& Jin, 1998). The electrophoresis was operated with $10 \mu \mathrm{L}$ of the sample.

The SDS-PAGE discontinuous buffer system of Schagger and Von Jagow (1987) was used and sample buffer was prepared (Grabski \& Burgess, 2001) from 10× Tris/glycine/SDS electrophoresis buffer. Any kD ${ }^{\mathrm{TM}}$ Mini-Protean ${ }^{\circledR}$ TGX Stain-Free ${ }^{\mathrm{TM}}$ protein gels (Bio-Rad Laboratories Ltd.) were used for separating the caseins in the electrophoresis. Precision Plus Protein $^{\mathrm{TM}}$ Unstained Protein Standards, Strep-tagged recombinant proteins (10-250 kDa) (Cat \# 1610363; Bio-Rad Laboratories Ltd.) was used for identification of respective caseins. Gel image 

acquisition was performed using stain free, Gel Doc ${ }^{\mathrm{TM}}$ EZ System (Bio-Rad Laboratories Ltd.) and the relative intensity of each band was used to determine casein degradation.

\subsection{Texture analysis}

Uniaxial compression was made using a TA.XT plus Texture Analyzer (Stable Micro Systems Ltd., Godalming, UK). Cylindrical cheese samples $20 \mathrm{~mm}$ high and $13 \mathrm{~mm}$ diameter were prepared by vertically punching the cubic cheese samples at $5^{\circ} \mathrm{C}$ gently using a lubricated cork borer, and analysed immediately. The compression test was performed with $25 \mathrm{~mm}$ diameter cylindrical probe, at $0.83 \mathrm{~mm} \mathrm{sec}^{-1}$ speed to $70 \%$ of the initial height of the sample (Wium, Gross, \& Qvist, 1997). The compression probe was lubricated with oil between each analysis. Stress at fracture $\left(\sigma_{\mathrm{f}}\right)$ (i.e., stress corrected for the change in sample area) and Young's modulus $\left(\mathrm{Y}_{\mathrm{m}}\right)$ (i.e., the slope at the initial $5 \%$ of compression) were determined to characterise the firmness and the initial structure of the cheese, respectively (O'Callaghan \& Guinee, 2004). Rheological analysis was performed in triplicate.

\subsection{Analysis of volatile compounds}

Volatile compounds were analysed by dynamic headspace sampling/gas chromatographymass spectrometry (DHS/GC-MS). The frozen cheese samples were grated and $20 \mathrm{~g}$ of the sample was transferred into a glass flask equipped with purge head and $60 \mathrm{~mL}$ of cold tap water was added to the flask and mixed gently. The samples were equilibrated for $10 \mathrm{~min}$ at $37^{\circ} \mathrm{C}$ in a water bath (Julabo, Buch and Holm, Copenhagen, Denmark) and the volatile compounds were collected in Tenax-TA traps (Buchem bv, Apendoorn, The Netherlands) by purging with a $\mathrm{N}_{2}$ flow of $100 \mathrm{~mL}$ 
$\min ^{-1}$ for $30 \mathrm{~min}$ at $37{ }^{\circ} \mathrm{C}$. The trapped volatile compounds were thermally desorbed (Turbo Matrix 350, Perkin Elmer, Shelton, WA, USA) and then cryo-focused in a Tenax TA cold trap (30 mg held at $5{ }^{\circ} \mathrm{C}$ ), which was subsequently heated at $300^{\circ} \mathrm{C}$ for 4 min (secondary desorption, outlet split 1:10). The desorbed compounds were analysed using a GC-MS (7890A GC-system interfaced with a 5975C VL MSD with Triple-Axis detector; Agilent Technologies, Palo Alto, CA, USA).

Compounds were separated on a DB-Wax capillary column $30 \mathrm{~m}$ long $\times 0.25 \mathrm{~mm}$ internal diameter, $0.50 \mu \mathrm{m}$ film thicknesses. The pressure of the column was 2.4 psi with an initial flow rate of $1.2 \mathrm{~mL}$ $\min ^{-1}\left(\mathrm{H}_{2}\right.$ as carrier gas). The column temperature was programmed $10 \mathrm{~min}$ at $30^{\circ} \mathrm{C}$, from $30{ }^{\circ} \mathrm{C}$ to $240{ }^{\circ} \mathrm{C}$ at $8{ }^{\circ} \mathrm{C} \min ^{-1}$, and finally $5 \min$ at $240{ }^{\circ} \mathrm{C}$. The mass spectrometer was operated in electron ionisation mode at $70 \mathrm{eV}$ and the mass to charge values between 15 and 300 were scanned. MSD Chemstation (Version E.02.00; Agilent Technologies) was used for data analysis. The commercial data base (Wiley 275.L, HP product no. G1035A) was used to match the spectra with the respective compounds. The peak areas were used to determine the relative abundance of each volatile in the experimental cheese samples. The GC-MS analysis was performed in duplicate.

\subsection{Descriptive sensory analysis}

The descriptive sensory analysis was performed using 10 trained panellists (Delahunty \& Drake, 2004). Panel recruitment and training in identifying the sensory descriptors for the cheese was according to the procedure described by Hootman (1992). Panellists were trained for each descriptive vocabulary of the four basic sensory modalities, i.e., aroma [buttery, silage, smoky, mouldy (musty) and pungent], appearance (watery, shiny, mouldy, openness and mottling), texture (crumbly, firmness, grainy, rubbery and smoothness), taste (sour, sweet, salty and bitter) (Lawlor \& Delahunty, 2000). Cheese samples were provided to the panellists and they were asked to scale the 
intensity of each descriptor on a $15 \mathrm{~cm}$ non-structured line scale. A feedback on the consensus and repeatability of their assessment was given to panels by analysing the data with PanelCheck software (V1.4.0; Copenhagen, Denmark) during the training and between each assessment to improve their rating capacity. The cheese samples were coded with three digit codes and provided to the panel randomly (Ritvanen et al., 2005). A two way analysis of variance (ANOVA) was performed to identify significant $(p<0.05)$ product effects (Losó, Gere, Györey, Kókai, \& Sipos, 2012). The evaluation of the final product was performed independently at $20-22{ }^{\circ} \mathrm{C}$ in triplicate. Warm spring water was served for rinsing the mouth between each sample.

\subsection{Statistical analysis}

Physicochemical properties, soluble nitrogen fractions and texture data were analysed using SAS version 9.4 (SAS Institute, Cary, NC, USA). The general linear model (PROC GLM) procedure of SAS was used to determine significant $(p<0.05)$ differences. Least square means with significant $(p<0.05)$ differences were computed with multiple comparison tests (SHEFFE option in PROC GLM). The descriptive sensory profile data were analysed using PanelCheck software (V1.4.0) according to the work flow of Losó et al. (2012). Attributes with significance level difference above $5 \%(p<0.05)$ of product effect were considered in the analysis of the difference between each cheese samples. A spider web plot was used to characterise sensory attributes of the individual cheese samples and to indicate the score provided for significant attributes of each samples (Losó et al., 2012). Volatile aroma compounds data were auto-scaled and principal component analysis (PCA) was made using LatentiX 2.12 (Latentix ${ }^{\mathrm{TM}}$ 2016, Copenhagen, Denmark). 
231

232

233

234

\section{Results and discussion}

\subsection{Physicochemical properties}

The mean values of the composition of the camel milk used for cheese making were: $\mathrm{pH}$ $6.45 \pm 0.07 ; 3.49 \pm 0.09 \mathrm{~g}$ fat $100 \mathrm{~g}^{-1}$ cheese; $2.93 \pm 0.34 \mathrm{~g}$ protein $100 \mathrm{~g}^{-1}$ cheese; $11.65 \pm 0.28 \mathrm{~g}$ total solids $100 \mathrm{~g}^{-1}$ cheese; $4.08 \pm 0.44 \mathrm{~g}$ lactose $100 \mathrm{~g}^{-1}$ cheese. These values were in the range for camel milk composition reported previously (Konuspayeva, Faye, \& Loiseau, 2009). The composition of the experimental cheeses is indicated in Table 1 and were within the range of compositional properties reported for soft brined cheeses (Anifantakis, 1996; Prasad \& Alvarez, 1999).

\subsection{Proteolysis}

\subsubsection{Soluble nitrogen fraction}

The soluble nitrogen fractions of cheese were used as an index of proteolysis. Total nitrogen (TN) and all the three types of soluble nitrogen fractions generated from the cheese were all significantly $(p<0.05)$ affected by ripening time (Table 2). A similar rate in development of soluble nitrogen fractions has been reported for brined cheese varieties from milk of other species (Anifantakis, 1996). Nitrogen fractions of Feta cheese made from ewes' milk increased throughout the ripening period (Katsiari, Alichanidis, Voutsinas, \& Roussis, 2000). Increasing the coagulant level resulted in a significantly $(p<0.05)$ higher value for soluble nitrogen fractions (i.e., $\mathrm{pH} 4.4$, TCA and PTA) (Table 3). A significantly $(p<0.001)$ higher formation of soluble nitrogen fractions was recorded for cheese made with a higher coagulant level $\left(85 \mathrm{IMCU} \mathrm{L}^{-1}\right)$ than for cheese made 
with the lower coagulant level (55 IMCU L $\left.{ }^{-1}\right)$ (Table 3). The formation rate of TCA soluble nitrogen fractions in our study is in general agreement with findings for soft brined cheese made from other milk types (Anifantakis, 1996; Mallatou, Pappa, \& Boumba, 2004).

\subsubsection{Casein proteolysis}

The extent of $\alpha_{\mathrm{S} 1 \text {-casein and } \beta \text {-casein degradation in soft brined cheese made from camel }}$ milk is indicated in Fig. 1a, b. The degradation rate of $\alpha_{\mathrm{S1}}$-casein and $\beta$-casein was different and this became more apparent after $20 \mathrm{~d}$ of ripening (Fig. 1). The effect of salt on $\alpha_{\mathrm{S1}}$-casein can be seen from Fig. 1a, 20 d, lanes 2 and 4: cheeses made with $55 \mathrm{IMCUL}^{-1}$ and $85 \mathrm{IMCUL}^{-1}$ and both brined in $5 \%$ salt have relatively higher intact $\alpha_{\mathrm{S} 1}$-casein than those cheeses on the same ripening day brined in $2 \%$ salt (i.e., lanes 1 and 3 ). The degradation of $\alpha_{\mathrm{S} 1}$-casein and $\beta$-casein was highest during the later stage of ripening and a number of degradation fragments with relative high mobility appeared during later period of ripening (Fig. 1). The increase of the band intensity of $\beta$-casein in

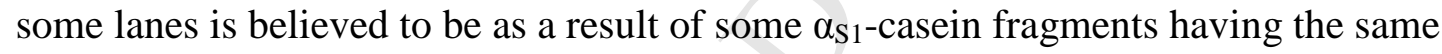
electrophoretic mobility as intact $\beta$-casein lanes (Fig. 1). Similar effects of ripening day for soft brined (Teleme cheese) cheese made from ewes' milk have been reported by Mallatou et al. (2004). For bovine caseins, Fox (1989) and Guinee and Fox (2004) indicated that $\alpha_{\mathrm{S} 1}$-casein is the preferred substrate for chymosin hydrolysis during cheese maturation compared with $\beta$-casein and that degradation of $\beta$-casein from bovine milk cheese by chymosin was reduced at $\geq 5 \% \mathrm{NaCl}$. The level of $\mathrm{NaCl}$ affected individual caseins by hydrating the casein (Guinee, 2004), which determined the accessibility of caseins to proteinases.

\subsection{Rheological properties}


Young's modulus $\left(\mathrm{Y}_{\mathrm{m}}\right)$ and stress at fracture $\left(\sigma_{\mathrm{f}}\right)$ of soft brined cheeses made from camel milk increased significantly $(p<0.05)$ with increasing salt in moisture $(\mathrm{S} / \mathrm{M})$ content and ripening time which were the highest on $60 \mathrm{~d}$ of ripening (Table 4). $\mathrm{Y}_{\mathrm{m}}$ of the cheeses was not significantly affected $(p>0.05)$ by coagulant level at $2 \% \mathrm{NaCl}$ in the brine (Table 5) These results are in agreement with those of Kaya (2002) and Prasad and Alvarez (1999) who reported that cheese hardness increases at higher salt $(\mathrm{NaCl})$ levels. The observed increase in rheological properties during ripening might be as a result of the increase in $\mathrm{S} / \mathrm{M}$ of the cheese. The initial structure of a rennet coagulated cheese during deformation is mainly due to the para-casein strand matrix (O'Callaghan \& Guinee, 2004) and addition of $\mathrm{NaCl}$ will affect the rheological properties of the cheese by hydration effects on the para-casein (Guinee \& Fox, 2004; O'Callaghan \& Guinee, 2004). Similarly, the proteolysis study showed that the level of salt has variable effect on the degradation of the individual caseins from soft brined camel milk cheese (Fig 1). The ratio of viscous to elastic character of a cheese can be influenced by degree of changes in casein hydration and aggregation, which could be due to the salt added to the cheese (Guinee \& Fox, 2004). Increasing the salt concentration promotes protein hydration and expansion (Pastorino et al., 2003) and also increases the integrity and formation of continuous junctions of the para-casein matrix which is maintained by hydrophobic and electrostatic attraction between aggregates in cheese matrix (O'Callaghan \& Guinee, 2004). The salt uptake of the cheese is determined by cheese shape, size, distance between cheese cubes, salting temperature, length of salting time and brine concentration (Guinee \& Fox, 2004).

Significantly $(p<0.05)$ lower $\mathrm{Y}_{\mathrm{m}}$ was observed for cheese made with $85 \mathrm{IMCU} \mathrm{L}^{-1}$ and $2 \%$ of $\mathrm{NaCl} \%(\mathrm{w} / \mathrm{w})$ in brine but $\mathrm{Y}_{\mathrm{m}}$ increased with increasing level of $\mathrm{NaCl}$ concentration in the brine for cheeses made at both coagulant levels (Table 5). O'Callaghan and Guinee (2004) and Lucey, Johnson, and Horne (2003) indicated that extent of hydrolysis of the para-casein matrix determines 
the rheological properties of cheese. The accessibility of these caseins for protease activity could be higher at the lower salt level (Guinee, 2004). Prasad and Alvarez (1999) also reported that increasing rennet concentration resulted in a weak texture for Feta type cheese. Therefore, at a coagulant concentration of $85 \mathrm{IMCU} \mathrm{L}^{-1}$, the para-casein strands in brined camel milk cheese might be hydrolysed and result in a softening of the cheese texture.

The S/M content of the cheese was also significantly $(p<0.05)$ higher for cheese made with $85 \mathrm{IMCU} \mathrm{L}^{-1}$ (Table 5) and this is in agreement with Prasad and Alvarez (1999) who also found that salt uptake of cheese was influenced by the concentration of rennet. Guinee (2004) also reported that the migration of $\mathrm{NaCl}$ to the cheese would be affected by structure of the cheese matrix, again the hydrolysis of para-casein at a higher coagulant level could have facilitated the salt uptake of brined camel milk cheese. The firmness $\left(\sigma_{\mathrm{f}}\right)$ of cheeses was significantly $(p<0.05)$ affected by coagulant level and $\mathrm{NaCl}$ concentration in the brine and this effect was more pronounced for cheese made using $55 \mathrm{IMCUL}^{-1}$ (Table 5).

By comparing the two cheeses made with different coagulant levels it could be concluded that $\sigma_{\mathrm{f}}$ of cheese made with $85 \mathrm{IMCU} \mathrm{L}^{-1}$ was not dependent on $\mathrm{NaCl}$ concentration in the brine and $\mathrm{S} / \mathrm{M}$ content of the cheeses (Table 5). S/M content of cheese is significantly $(p<0.05)$ higher on 60 $\mathrm{d}$ for both cheeses (Table 4). As indicated by O'Callaghan and Guinee (2004) at large deformations, the interior structure, i.e., the moisture and fat globules in the matrix, is responsible for the rheological properties of the cheese. Therefore, the variations in $\mathrm{NaCl}$ concentration which would lead to variation in level of moisture and other components between the interior and exterior part of brined cheeses in different brine might affected the rheology of the cheeses. Guinee (2004) indicated exchange of components between the interior and exterior part of the cheese results in moisture and other component variation during ripening. These migration of salt is also assisted by possible degradation of casein strands matrixes by the coagulant (Anifantakis, 1996), which could 
explain the observed non-significant $(p>0.05)$ difference in $\sigma_{\mathrm{f}}$ value at $85 \mathrm{IMCU} \mathrm{L}^{-1}$ at both $\mathrm{NaCl}$ concentrations (Table 5).

\subsection{Volatile compounds}

A total of 40 volatile aroma compounds were identified in the experimental cheese samples (Table 6). The groups of these compounds were aldehydes (9), alcohols (14), ketones (10), esters (4), sulphur compounds (2), and volatile acids (1). These groups of volatile compounds were also reported for cheese made from bovine milk by Curioni and Bosset (2002) and McSweeney and Sousa (2000). To gain an overview of the data, a PCA was carried out (Fig. 2) and most of the variation was explained by PC1 that can be interpreted as variation due to ripening time. All $0 \mathrm{~d}$ samples are placed to the left in the plot (negative scores in PC1), $30 \mathrm{~d}$ samples have slightly positive values, and most of the $60 \mathrm{~d}$ samples have high positive scores in PC1. This is because aroma compounds generated from $0 \mathrm{~d}$ samples are due to starter culture degradation of lactose; while degradation of protein and fat are the main contributors for aroma compounds in later stage of ripening which result in the development of ester and sulphur compounds.

Nine aldehydes were identified in the experimental cheeses and the degradation of amino acids can lead to formation of aldehydes via transamination or by Strecker degradation (Ardö, 2006). The straight chain aldehydes can provide green and herbaceous aroma notes to cheese (Curioni \& Bosset, 2002). Alcohols identified in the experimental cheeses can be biosynthesised via many metabolic pathways in general and they are reported as main aroma compounds of soft cheese (Ardö, 2006; Curioni \& Bosset, 2002). Phenylethanol and 2-propanol were seen to appear at the end of positive axis of PC1 in the current study (Fig. 2). Phenylethanol, 3-octanol and 2-propanol may provide a pleasant aroma of rose flower and fruity notes to the cheese (Curioni \& Bosset, 2002). 
All ketones except 3-octanone have negative PC1 loadings, indicating that they have the highest concentration in the early stages of ripening (Fig. 2). McSweeney and Sousa (2000) and Urbach (1997) reported that ketones are mostly produced by adjunct cultures, mainly from moulds, and are highly abundant in later stage of mould ripened cheeses. 3-Octanone is known for its green plant/musty/mouldy aroma (Urbach,1997); 2,3-butanedione (diacetyl) and acetoin (3-hydroxy-2butanone) provide buttery flavour to the cheese (Curioni \& Bosset, 2002).

The two ester compounds (i.e., ethyl 3-methylbutanoate and ethyl hexanoate) were shown to be most abundant in later stage of the ripening (Fig. 2) as they had positive loadings in PC1. Esters can be formed either from purely chemical interaction between alcohol and free fatty acids (McSweeney \& Sousa, 2000) that could result in either ethyl hexanoate or ethyl acetate (Marilley \& Casey, 2004). Esters can also be formed from the catabolism of amino acids and lactose fermentation (Curioni \& Bosset, 2002). Ethyl hexanoate or esters provide a fruity/pineapple flavour to cheese (Curioni \& Bosset, 2002; Yuceer et al., 2009). The observed variance in ester compounds explained by PC2 (Fig. 2) could be due to the fact that the level of the coagulant added resulted in higher amounts of substrate (amino acids) (Smit, Smit, \& Engels, 2005) and salt added to cheeses could also affect the coagulant proteolysis activity (Guinee \& Fox, 2004).

Two sulphur compounds (i.e., dimethylsulphide and dimethyldisulphide) identified in cheese could originate from sulphur containing amino acids such as methionine and cysteine (McSweeney \& Sousa, 2000). Dimethyldisulphide had positive loading value (PC1 and PC2), which shows that the production of this compound is higher in later stage of ripening and for higher coagulant level (85 IMCU L ${ }^{-1}$ ). These sulphur compounds can bestow garlic or onion flavour to cheese (McSweeney \& Sousa, 2000).

Acetic acid is the volatile acid identified in the experimental cheese. It can be produced from fatty acids (C4-C12) (Curioni \& Bosset, 2002), from citrate metabolism (Kondyli, Massouras, 
375 Katsiari, \& Voutsinas, 2003) and also from amino acid, i.e., threonine, catabolism (Ardö, 2006).

376 The increase of acetic acid during the ripening in this study is in agreement with the reports of

377 Curioni and Bosset (2002) and Kondyli et al. (2003). Acetic acid provides a flavour note of sour or 378 vinegar (Molimard \& Spinnler, 1996; Yuceer et al., 2009).

The overall different patterns observed in development of aroma compounds identified in

\subsection{Descriptive sensory evaluation}

Descriptive sensory profiles of cheese samples are shown in Fig. 3 and only the attributes for which the panellists could significantly $(p<0.05)$ differentiate between samples along the ripening period are shown as spider web plots. Sensory attributes [i.e., aroma (silage, mouldy/musty), taste (saltiness, sweet, sour), appearance (watery) and texture (firmness)] were significantly $(p<0.05)$ differentiated by the panellists and varied between cheeses (Fig. 3). During the ripening period, the intensity of silage and mouldy (musty) aroma showed a slight increase (Fig. 3a, c). The response from the panellists generally agrees with the aroma compounds identified and their patterns from the experimental cheeses, as the overall concentration of aroma compounds generated from the cheeses increased during ripening as indicated by the first principal component (PC1) (Fig. 3). This is due to the fact that different flavour compounds were generated during the 
ripening of the cheese as a result of complex biochemical reactions (McSweeney \& Sousa, 2000; Urbach, 1993; 1997). The panellists provide a higher score for saltiness, sourness, silage, mouldy and firmness for cheeses made with the higher salt (5\% NaCl) level on $30 \mathrm{~d}$ and $60 \mathrm{~d}$ (Fig. 3b,c), hence these attributes were dependent on salt concentration. The sensory attributes of the experimental cheeses resembled most brined cheese made from milk of other species which can be characterised as salty, sour and firm (Anifantakis, 1996). Closely looking into the sensory descriptors provided by the panellists and the specific volatiles generated from the cheeses, it can be concluded that the sensory descriptors provided by the panellists would precisely describe the cheeses even though cheese flavour is a balance between each volatile and the threshold of detection level.

\section{Conclusion}

\section{Cheese making with $85 \mathrm{IMCU} \mathrm{L}^{-1}$ coagulant resulted in a higher degradation of caseins than} was obtained with $55 \mathrm{IMCU} \mathrm{L}^{-1}$ coagulant. Similar to the case for brined cheese from bovine milk, $\beta$-casein in brined camel cheese was clearly seen to be degraded in later stage of ripening while $\alpha_{S_{1}}{ }^{-}$ casein remained more intact. The rheological properties $\left(\mathrm{Y}_{\mathrm{m}}\right.$ and $\left.\sigma_{\mathrm{f}}\right)$ and the accumulation of individual volatile aroma compounds of brined camel cheeses were dependent on the time of ripening, salt and coagulant levels. S/M content of cheese increased with increase in brine concertation and ripening time. Even though the $\mathrm{Y}_{\mathrm{m}}$ and $\sigma_{\mathrm{f}}$ increased with increasing salt level, a softer brined cheese texture was noted for cheese made with $85 \mathrm{IMCU} \mathrm{L}^{-1}$. Furthermore, the $\sigma_{\mathrm{f}}$ was not dependent on $\mathrm{NaCl}$ concentration at a higher coagulant concentration. The developments of volatile aroma compounds from the cheeses were mainly influenced by ripening time. However, both salt and coagulant level also exerted a significant effect on the development of different 
423 volatile aroma compounds, which could be due to the proteolysis effect of coagulant and salt on

424 proteolytic enzymes that could influence the production of free amino acids. The overall volatile 425 aroma compounds generated in the experimental cheeses were similar to that of brined cheeses 426 made from other milk types. The trend in the development of these volatiles also explains the 427 variation in sensory descriptors provided by the panellists. Soft brined camel milk can be described 428 with salty, sour and firm sensory descriptors.

\section{Acknowledgements}

The authors are grateful for the assistance received from Prof. Karsten Bruun Qvist with respect to experimental design and final data analysis. We also would like to acknowledge the technical support received from Belinda Nielsen, University of Copenhagen in designing the sensory evaluation. The financial support to conduct this study was received from the Danish

References

Anifantakis, E. M. (1996). Traditional feta cheese. In R. K. Robinson, \& A. Y. Tamime (Eds.), Feta and related cheeses (pp. 49-68). Cambridge, UK: Woodhead Publishing Limited.

AOAC. (1995). Official methods of analysis, $16^{\text {th }}$ edn. AOAC no 925.23. Washington, DC, USA: Association of Official Analytical Chemists. 
Ardö, Y., \& Polychroniadou, A. (1999). Laboratory manual for chemical analysis of cheese. Luxembourg: European Communities, Office for Official Publications of the European Communities.

Benkerroum, N., Dehhaoui, M., El Fayq, A., \& Tlaiha, R. (2011). The effect of concentration of chymosin on the yield and sensory properties of camel cheese and on its microbiological quality. International Journal of Dairy Technology, 64, 232-239.

Curioni, P. M. G., \& Bosset, J. O. (2002). Key odorants in various cheese types as determined by gas chromatography-olfactometry. International Dairy Journal, 12, 959-984.

Delahunty, C. M., \& Drake, M. A. (2004). Sensory character of cheese and its evaluation. In P. F. Fox, P. L. H. McSweeney, T. M. Cogan, \& T. P. Guinee (Eds.), Cheese: Chemistry, physics and microbiology: General aspects (pp. 455-487). London, UK: Elsevier Academic Press.

Drake, M. A. (2007). Sensory analysis of dairy foods. Journal of Dairy Science, 90, 4925-4937.

Essex, E. (1969). Objective measurements for texture in foods. Journal of Texture Studies, 1, 19-37.

Fox, P. F. (1989). Proteolysis during cheese manufacture and ripening. Journal of Dairy Science, 72, 1379-1400.

Grabski, A. C., \& Burgess, R. R. (2001). Preparation of protein samples for SDS-polyacrylamide gel electrophoresis: procedures and tips. inNovations, 13, 10-12.

Guinee, T. P. (2004). Salting and the role of salt in cheese. International Journal of Dairy Technology, 57, 99-109.

Guinee, T. P., \& Fox, P. F. (2004). Salt in cheese: Physical, chemical and biological aspects. In P. F. Fox, P. L. H. McSweeney, T. M. Cogan \& T. P. Guinee (Eds.), Cheese: Chemistry, physics and microbiology (pp 207-261). London, UK: Elsevier Academic Press.

Hailu, Y., Seifu, E., \& Yilma, Z. (2014). Physicochemical properties and consumer acceptability of soft unripened cheese made from camel milk using crude extract of ginger (Zingiber 
officinale) as coagulant. African Journal of Food Science, 8, 87-91.

Hootman, R. C. (1992). Manual on descriptive analysis testing for sensory evaluation ( $1^{\text {st }}$ edn., Chapt. 2). Philadelphia, PA, USA: ASTM Publisher.

ISO594/:IDF88. (2006). Cheese and processed cheese products-determination of chloride contentpotentiometric titration method. Brussels, Belgium: International Dairy Federation.

Kappeler, S. R., Rahbek-Nielsen, H., Farah, Z., Puhan, Z., Hansen, E. B., \& Johansen, E. (2006). Characterization of recombinant camel chymosin reveals superior properties for the coagulation of bovine and camel milk. Biochemical and Biophysical Research Communications, 342, 647-654.

Katsiari, M. C., Alichanidis, E., Voutsinas, L. P., \& Roussis, I. G. (2000). Proteolysis in reduced sodium Feta cheese made by partial substitution of $\mathrm{NaCl}$ by $\mathrm{KCl}$. International Dairy Journal, 10, 635-646.

Kaya, S. (2002). Effect of salt on hardness and whiteness of Gaziantep cheese during short-term brining. Journal of Food Engineering, 52, 155-159.

Kondyli, E., Massouras, T., Katsiari, M. C., \& Voutsinas, L. P. (2003). Free fatty acids and volatile compounds in low-fat Kefalograviera-type cheese made with commercial adjunct cultures. International Dairy Journal, 13, 47-54.

Konuspayeva, G., Camier, B., Aleilawi, N., Al-Shumeimyri, M., Al-Hammad, K., Algruin, K., et al. (2016). Manufacture of dry and brine-salted soft camel cheeses for the camel dairy industry. International Journal of Dairy Technology, 68, 1-10.

Konuspayeva, G., Faye, B., \& Loiseau, G. (2009). The composition of camel milk: A meta-analysis of the literature data. Journal of Food Composition and Analysis, 22, 95-101.

Lawlor, J. B., \& Delahunty, C. M. (2000). The sensory profile and consumer preference for ten speciality cheeses. International Journal of Dairy Technology, 53, 28-36. 
Lawrence, R. C., Creamer, L. K., \& Gilles, J. (1987). Texture development during cheese ripening. Journal of Dairy Science, 70, 1748-1760.

Losó, V., Gere, A., Györey, A., Kókai, Z., \& Sipos, L. (2012). Comparison of the performance of a trained and an untrained sensory panel on sweetcorn varieties with the PanelCheck software. Applied Studies in Agribusiness and Commerce - APSTRACT, 2012/1-2, 77-83.

Lucey, J. A, Johnson, M. E., \& Horne, D. S. (2003). Perspectives on the basis of the rheology and texture properties of cheese. Journal of Dairy Science, 86, 2725-2743.

Mallatou, H., Pappa, E. C., \& Boumba, V. A., (2004). Proteolysis in Teleme cheese made from ewes', goats' or a mixture of ewes' and goats' milk. International Dairy Journal, 14, 977987.

Marilley, L., \& Casey, M. G. (2004). Flavours of cheese products: Metabolic pathways, analytical tools and identification of producing strains. International Journal of Food Microbiology, 90, 139-159.

McSweeney, P. L. H. (2004). Biochemistry of cheese ripening: Introduction and overview. In P. F. Fox, P. L. H. McSweeney, T. M. Cogan \& T. P. Guinee (Eds.), Cheese: Chemistry, physics and microbiology (pp. 347-360). London, UK: Elsevier Academic Press.

McSweeney, P. L. H., \& Sousa, M. J. (2000). Biochemical pathways for the production of flavour compounds in cheeses during ripening: A review. Lait, 80, 293-324.

Molimard, P., \& Spinnler, H. E. (1996). Compounds involved in the flavor of surface mold-Ripened cheeses: Origins and properties. Journal of Dairy Science, 79, 169-184.

O’Callaghan, D. J. \& Guinee, T. P. (2004). Rheology and texture of cheese. In P. F. Fox, P. L. H. McSweeney, T. M. Cogan, \& T. P. Guinee (Eds.), Cheese: Chemistry, physics and microbiology (pp. 511-541). London, UK: Elsevier Academic Press.

Pappas, C. P., Kondyli, E., Voutsinas, L. P., \& Mallatou, H. (1996). Effects of salting method and 

storage time on composition and quality of feta cheese. Journal of the Society of Dairy Technology, 49, 113-118.

Park, Y., \& Jin, Y. (1998). Proteolytic patterns of Caciotta and Monterey Jack hard goat milk cheeses as evaluated by SDS-PAGE and densitometric analyses. Small Ruminant Research, 28, 263-272.

Pastorino, A. J., Hansen, C. L., \& McMahon, D. J. (2003). Effect of salt on structure-function relationships of cheese. Journal of Dairy Science, 86, 60-69.

Prasad, N., \& Alvarez, V. B. (1999). Effect of salt and chymosin on the physico-chemical properties of feta cheese during ripening. Journal of Dairy Science, 82, 1061-1067.

Ritvanen, T., Lampolahti, S., Lilleberg, L., Tupasela, T., Isoniemi, M., Appelbye, U., et al. (2005). Sensory evaluation, chemical composition and consumer acceptance of full fat and reduced fat cheeses in the Finnish market. Food Quality and Preference, 16, 479-492.

Schagger, H., \& Von Jagow, G. (1987). Tricine-sodium dodecylsulfate-polyacrylamide gel electrophoresis for the separation of proteins in the range from 1 to $100 \mathrm{kDa}$. Analytical. Biochemistry, 166, 368-379.

Smit, G., Smit, B. A., \& Engels, W. J. M. (2005). Flavour formation by lactic acid bacteria and biochemical flavour profiling of cheese products. FEMS Microbiology Reviews, 29, 591610.

Urbach, G. (1993). Relations between cheese flavour and chemical composition. International Dairy Journal, 3, 389-422.

Urbach, G. (1997). The flavour of milk and dairy products. II. Cheese: Contribution of volatile compounds. International Journal of Dairy Technology, 50, 79-89.

Wium, H., Gross, M., \& Qvist, K. B. (1997). Uniaxial compression of UF-feta cheese related to sensory texture analysis. Journal of Texture Studies, 28, 455-476. 
543 Yuceer, Y. K., Tuncel, B., Guneser, O., Engin, B., Isleten, M., Yasar, K., et al. (2009). cheese. Journal of Dairy Science, 92, 4146-4157. 


\section{Figure legends}

Fig. 1. Electrophoresis images of casein from soft brined cheese made from camel milk.

Casein from cheese made with different level of coagulant and salt level and sampled at (a) 0 and $20 \mathrm{~d}$ and (b) 40 and $60 \mathrm{~d}$. For each day data set, lane 1: $55 \mathrm{IMCU} \mathrm{L}^{-1}, 2 \%(\mathrm{w} / \mathrm{w}) \mathrm{NaCl}$; lane 2: 55 IMCU L ${ }^{-1}, 5 \%(w / w) ~ N a C l$; lane: 3, $85 \mathrm{IMCU} \mathrm{L}^{-1}, 2 \%(\mathrm{w} / \mathrm{w}) \mathrm{NaCl}$; lane 4: 85

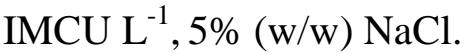

Fig. 2. PCA plots (scores, top; loadings, bottom) for the volatile aroma compounds identified from soft brined camel milk cheese. The four cheese types are designated as LCLS (55 IMCU $\mathrm{L}^{-1}$ coagulant; $\left.2 \%, \mathrm{w} / \mathrm{w}, \mathrm{NaCl}\right)$; LCHS (55 IMCU L $\mathrm{I}^{-1}$ coagulant; 5\%, w/w, NaCl); HCLS (85 IMCU L ${ }^{-1}$ coagulant; $2 \%$, w/w, $\mathrm{NaCl}$ ); $\mathrm{HCHS}\left(85 \mathrm{IMCU} \mathrm{L}^{-1}\right.$ coagulant; $5 \%$, w/w, NaCl) and ripening day is indicated. Average peak areas of each compounds were used to compute principal component analysis. Numbers in the plot represents individual volatile compounds listed in Table 6.

Fig. 3. Sensory descriptors for soft brined cheese made from camel milk on $0 \mathrm{~d}$ (a), $30 \mathrm{~d}$ (b) and $60 \mathrm{~d}(\mathrm{c})$ of ripening. Soft cheese made with $(\mathbf{O}) 55 \mathrm{IMCU} \mathrm{L}^{-1}$ brined in $2 \%(\mathrm{w} / \mathrm{w}) \mathrm{NaCl}$,

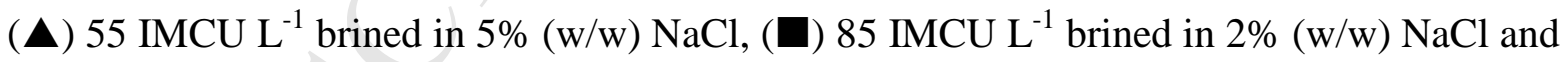

$(\diamond) 85 \mathrm{IMCU} \mathrm{L}^{-1}$ brined in $5 \%(\mathrm{w} / \mathrm{w}) \mathrm{NaCl}$. Average values of 10 panellists' evaluations in triplicate. 


\section{Table 1}

2

3 Composition of soft brined cheese made from camel milk over $60 \mathrm{~d}$ of ripening. ${ }^{\text {a }}$

4

\begin{tabular}{llllll}
\hline Day & $\mathrm{pH}$ & Fat & $\begin{array}{l}\text { Total solids } \\
\left(\mathrm{g} 100 \mathrm{~g}^{-1}\right)\end{array}$ & $\begin{array}{l}\text { Protein } \\
\left(\mathrm{g} 100 \mathrm{~g} \mathrm{~g}^{-1}\right)\end{array}$ & $\begin{array}{l}\text { Ash } \\
\left({\left.\mathrm{g} 100 \mathrm{~g}^{-1}\right)}\right.\end{array}$ \\
\hline 0 & $4.73 \pm 0.02^{\mathrm{a}}$ & $26.0 \pm 0.4^{\mathrm{a}}$ & $45.42 \pm 0.64^{\mathrm{a}}$ & $20.37 \pm 0.93^{\mathrm{a}}$ & $1.48 \pm 0.15^{\mathrm{b}}$ \\
30 & $4.46 \pm 0.02^{\mathrm{b}}$ & $23.81 \pm 0.4^{\mathrm{b}}$ & $38.36 \pm 0.64^{\mathrm{b}}$ & $17.37 \pm 0.93^{\mathrm{ab}}$ & $3.07 \pm 0.15^{\mathrm{a}}$ \\
60 & $4.53 \pm 0.02^{\mathrm{c}}$ & $24.0 \pm 0.4^{\mathrm{b}}$ & $36.46 \pm 0.64^{\mathrm{b}}$ & $14.39 \pm 0.93^{\mathrm{b}}$ & $2.94 \pm 0.15^{\mathrm{a}}$ \\
\hline
\end{tabular}

5

$6 \quad{ }^{a}$ Values are least square means \pm standard error $(n=8)$ of the four cheeses; means with the same 7 superscript letter within a column are not significantly different $(p>0.05)$.

8

9 
10

11

12

13

14

\begin{tabular}{lllll}
\hline Day & TN & pH 4.4 SN & TCA-SN & PTA-SN \\
\hline 0 & $3.19 \pm 0.139^{\mathrm{a}}$ & $11.70 \pm 1.848^{\mathrm{b}}$ & $4.17 \pm 0.981^{\mathrm{b}}$ & $3.34 \pm 0.760^{\mathrm{b}}$ \\
20 & $2.65 \pm 0.127^{\mathrm{ab}}$ & $12.87 \pm 1.653^{\mathrm{b}}$ & $5.64 \pm 0.885^{\mathrm{b}}$ & $5.16 \pm 0.724^{\mathrm{b}}$ \\
40 & $2.43 \pm 0.127^{\mathrm{bc}}$ & $16.27 \pm 1.848^{\mathrm{ab}}$ & $11.73 \pm 0.981^{\mathrm{a}}$ & $9.919 \pm 0.842^{\mathrm{a}}$ \\
60 & $2.07 \pm 0.142^{\mathrm{c}}$ & $23.98 \pm 1.653^{\mathrm{a}}$ & $14.27 \pm 1.034^{\mathrm{a}}$ & $11.79 \pm 0.887^{\mathrm{a}}$
\end{tabular}

15

16

17

18

19

20

21

\section{Table 2}

Total nitrogen and soluble nitrogen fractions during ripening of $60 \mathrm{~d}$ of soft brined cheese made from camel milk. ${ }^{a}$

a Abbreviations are: TN, total nitrogen; $\mathrm{pH} 4.4 \mathrm{SN}, \mathrm{pH} 4.4$ soluble nitrogen; TCA-SN, trichloroacetic acid soluble nitrogen; PTA-SN, phosphotungstic acid soluble nitrogen. Values (\%) are least square means \pm standard error $(n=8)$ of the four cheeses; means with the same superscript letter within a column are not significantly different $(p>0.05)$. 
Table 3

23

24 Soluble nitrogen fractions of cheese made with different coagulant levels. ${ }^{\text {a }}$

25

\begin{tabular}{lccc}
\hline Coagulant level & $\mathrm{pH} 4.4 \mathrm{SN}$ & TCA-SN & PTA-SN \\
\hline $55 \mathrm{IMCU} \mathrm{L}^{-1}$ & $11.64 \pm 1.66^{\mathrm{b}}$ & $7.31 \pm 0.68^{\mathrm{b}}$ & $6.42 \pm 0.58^{\mathrm{b}}$ \\
$85 \mathrm{IMCU} \mathrm{L}^{-1}$ & $19.39 \pm 1.66^{\mathrm{a}}$ & $10.59 \pm 0.69^{\mathrm{a}}$ & $8.68 \pm 0.56^{\mathrm{a}}$ \\
\hline
\end{tabular}

26

27

${ }^{\mathrm{a}}$ Abbreviations are: $\mathrm{pH}$ 4.4 SN, $\mathrm{pH} 4.4$ soluble nitrogen; TCA-SN, trichloroacetic acid soluble

28 nitrogen; PTA-SN, phosphotungstic acid soluble nitrogen; ICMU, international milk clotting units.

29 Values $(\%)$ are least square means \pm standard error $(n=12)$ of the cheese from both brine

30 concentrations; means with the same superscript letter within a column are not significantly

31 different $(p>0.05)$.

32

33

34 
35

36

37

\begin{tabular}{|c|c|c|c|c|c|}
\hline \multirow[t]{2}{*}{ Day } & \multicolumn{2}{|l|}{$\mathrm{Y}_{\mathrm{m}}(\mathrm{Kpa})$} & \multicolumn{2}{|l|}{$\sigma_{\mathrm{f}}(\mathrm{Kpa})$} & $\mathrm{S} / \mathrm{M}\left(\mathrm{g} 100 \mathrm{~g}^{-1}\right)$ \\
\hline & $2 \% \mathrm{NaCl}$ & $5 \% \mathrm{NaCl}$ & $2 \% \mathrm{NaCl}$ & $5 \% \mathrm{NaCl}$ & $2 \% \mathrm{NaCl}$ \\
\hline$\overline{0}$ & $12.40 \pm 3.96^{\mathrm{d}}$ & $10.97 \pm 3.96^{\mathrm{d}}$ & $9.34 \pm 1.12^{b}$ & $11.02 \pm 1.12^{b}$ & $0.46 \pm 0.04^{\mathrm{d}} \quad 0.51 \pm 0.04^{\mathrm{d}}$ \\
\hline 30 & $30.96 \pm 4.43^{\mathrm{d}}$ & $60.13 \pm 3.96^{c}$ & $12.34 \pm 1.12^{b}$ & $22.56 \pm 1.25^{\mathrm{a}}$ & $3.38 \pm 0.04^{\mathrm{c}} \quad 5.71 \pm 0.04^{\mathrm{b}}$ \\
\hline 60 & $104.25 \pm 4.83^{b}$ & $232.76 \pm 4.85^{\mathrm{a}}$ & $25.96 \pm 1.37^{\mathrm{a}}$ & $23.97 \pm 1.37^{\mathrm{a}}$ & $3.35 \pm 0.04^{\mathrm{c}} \quad 6.20 \pm 0.04^{\mathrm{a}}$ \\
\hline
\end{tabular}

38

39

40

41

42

\section{Table 4}

Effect of ripening day on Young's modulus $\left(\mathrm{Y}_{\mathrm{m}}\right)$, stress at fracture $\left(\sigma_{\mathrm{f}}\right)$ and salt in moisture $(\mathrm{S} / \mathrm{M})$ of cheeses. ${ }^{\mathrm{a}}$

${ }^{\text {a }}$ Values are least square means \pm standard error $(n=4)$ of the two cheeses; means with the same superscript letters for each variable in column are not significantly different $(p<0.05)$. 
43

44

45

46

\begin{tabular}{|c|c|c|c|c|c|c|}
\hline \multirow{2}{*}{$\begin{array}{l}\text { Coagulant } \\
\left(\mathrm{IMCU} \mathrm{L}^{-1}\right)\end{array}$} & \multicolumn{2}{|l|}{$\mathrm{Y}_{\mathrm{m}}(\mathrm{Kpa})$} & \multicolumn{2}{|l|}{$\sigma_{\mathrm{f}}(\mathrm{Kpa})$} & \multicolumn{2}{|c|}{$\mathrm{S} / \mathrm{M}\left(\mathrm{g} 100 \mathrm{~g}^{-1}\right)$} \\
\hline & $2 \% \mathrm{NaCl}$ & $5 \% \mathrm{NaCl}$ & $2 \% \mathrm{NaCl}$ & $5 \% \mathrm{NaCl}$ & $2 \% \mathrm{NaCl}$ & $5 \% \mathrm{NaCl}$ \\
\hline 55 & $54.44 \pm 3.49^{\mathrm{bc}}$ & $134.54 \pm 3.49^{\mathrm{a}}$ & $14.89 \pm 1.0^{b}$ & $22.62 \pm 1.05^{\mathrm{a}}$ & $2.39 \pm 0.03^{c}$ & $3.84 \pm 0.03^{b}$ \\
\hline 35 & $43.97 \pm 3.49^{c}$ & $68.03 \pm 3.49^{b}$ & $16.88 \pm 1.0^{\mathrm{b}}$ & $15.75 \pm 1.05^{\mathrm{b}}$ & $2.40 \pm 0.03^{\mathrm{c}}$ & $4.40 \pm 0.03^{\mathrm{a}}$ \\
\hline
\end{tabular}

47

48

49

50

51

52

53

54 55

56

57

58

\section{Table 5}

Effect of coagulant and brine concertation on Young's modulus $\left(\mathrm{Y}_{\mathrm{m}}\right)$, stress at fracture $\left(\sigma_{\mathrm{f}}\right)$ and salt in moisture $(\mathrm{S} / \mathrm{M})$ of cheese. ${ }^{\text {a }}$

${ }^{a}$ Values in the table are least square means \pm standard error $(n=6)$ of the two cheeses during ripening; means with the same superscript letters for each variable in column are not significantly different $(p>0.05)$. 2 6 7 58 


\begin{tabular}{lllll}
\hline Aldehydes & Alcohols & Ketone & Esters & Sulphur compounds \\
\hline Acetaldehyde (1) & 2-Propanol (10) & Acetone (24) & Eolatile acid \\
2-Methylpropanal (2) & Ethanol (11) & 2-Butanone (25) & Ethyl hexanoate (35) & Dimethylsulphide (38) \\
2-Methylbutanal (3) & 2-Butanol (12) & 2.3-Butanetione (26) & Ethyl-4-ethoxybenzoate (36) & \\
3-Ethylbutanal (4) & Propanol (13) & 2.3-Pentanedione (27) & Ethyl-3-methylbutanoate (37) & \\
Hexanal (5) & 1-Pentanol (14) & 2-Heptanone (28) & & \\
Heptanal (6) & 1-Hexanol (15) & 3-Octanone (29) & & \\
Nonanal (7) & 3-Octanol (16) & Acetoin (30) & \\
Benzaldehyde (8) & 1-Heptanol (17) & 2-Nonanone (31) & \\
Benzeneacetaldehyde (9) & 2-Octen-1-ol (18) & Acetophenone (32) & \\
& 1-Nonanol (19) & 2-Hydroxy-3-pentanone(33) & & \\
& Phenol (20) & & & \\
& 2-Methyl-1-propanol (21) & & & \\
& Phenylethanol (22) & & & \\
& 3-Methyl-1-butanol (23) & & & \\
\end{tabular}

60 Volatile aroma compounds identified from soft brined camel cheese ripened for $60 \mathrm{~d} .^{\mathrm{a}}$

$62{ }^{\text {a }}$ Values in parenthesis are the numbers used to indicate the location of individual volatile compounds on the PCA plot of Fig. 3. 


\section{ACCEPTED MANUSCRIPT}

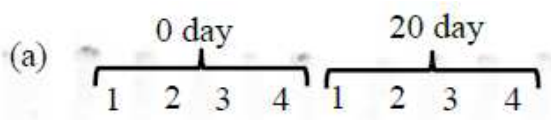

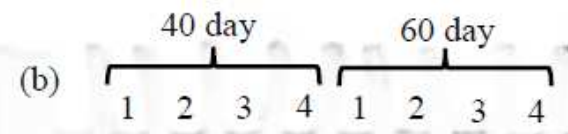
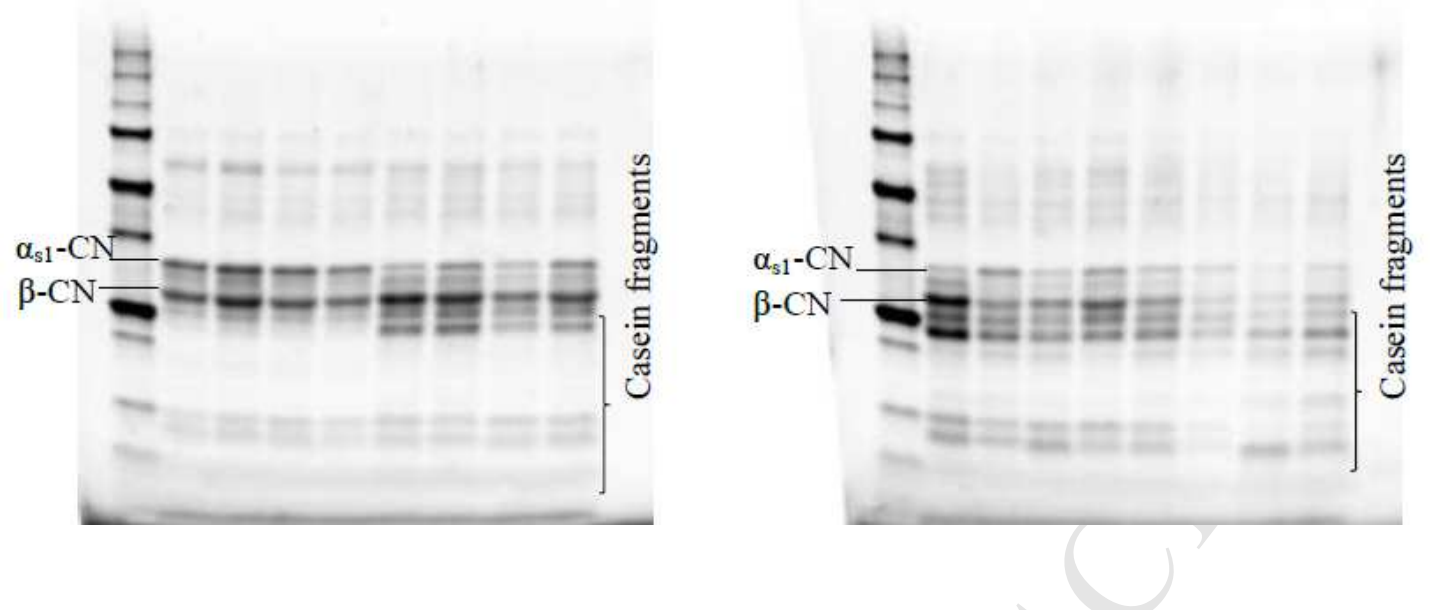

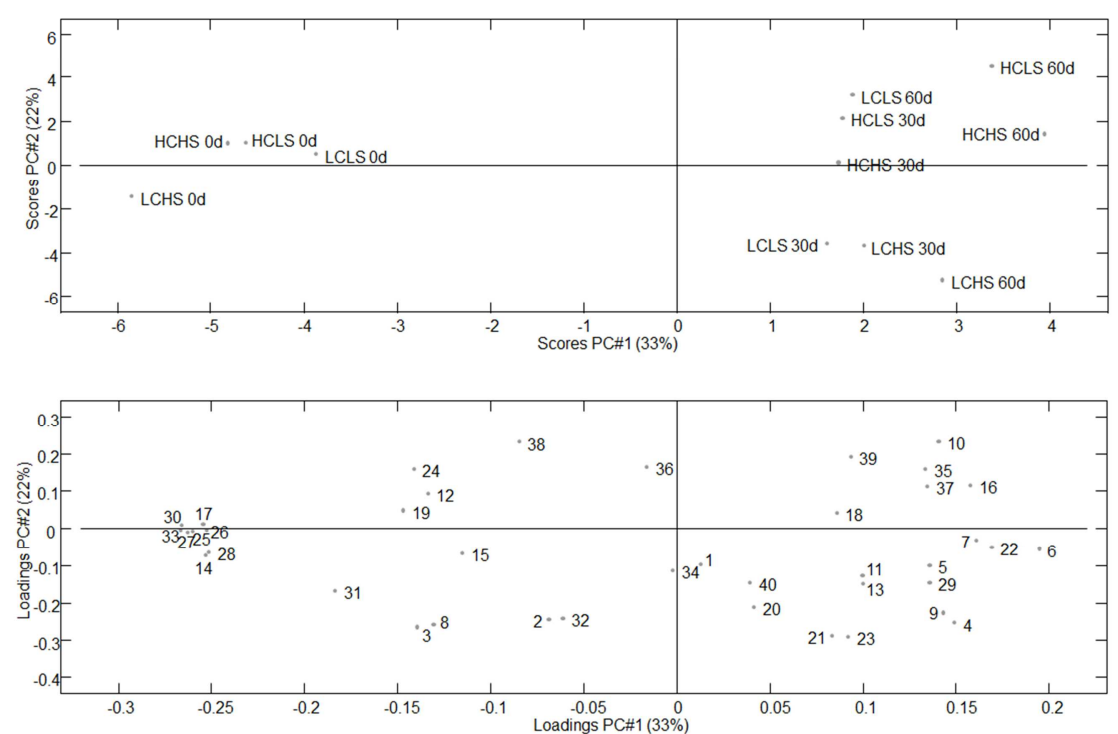


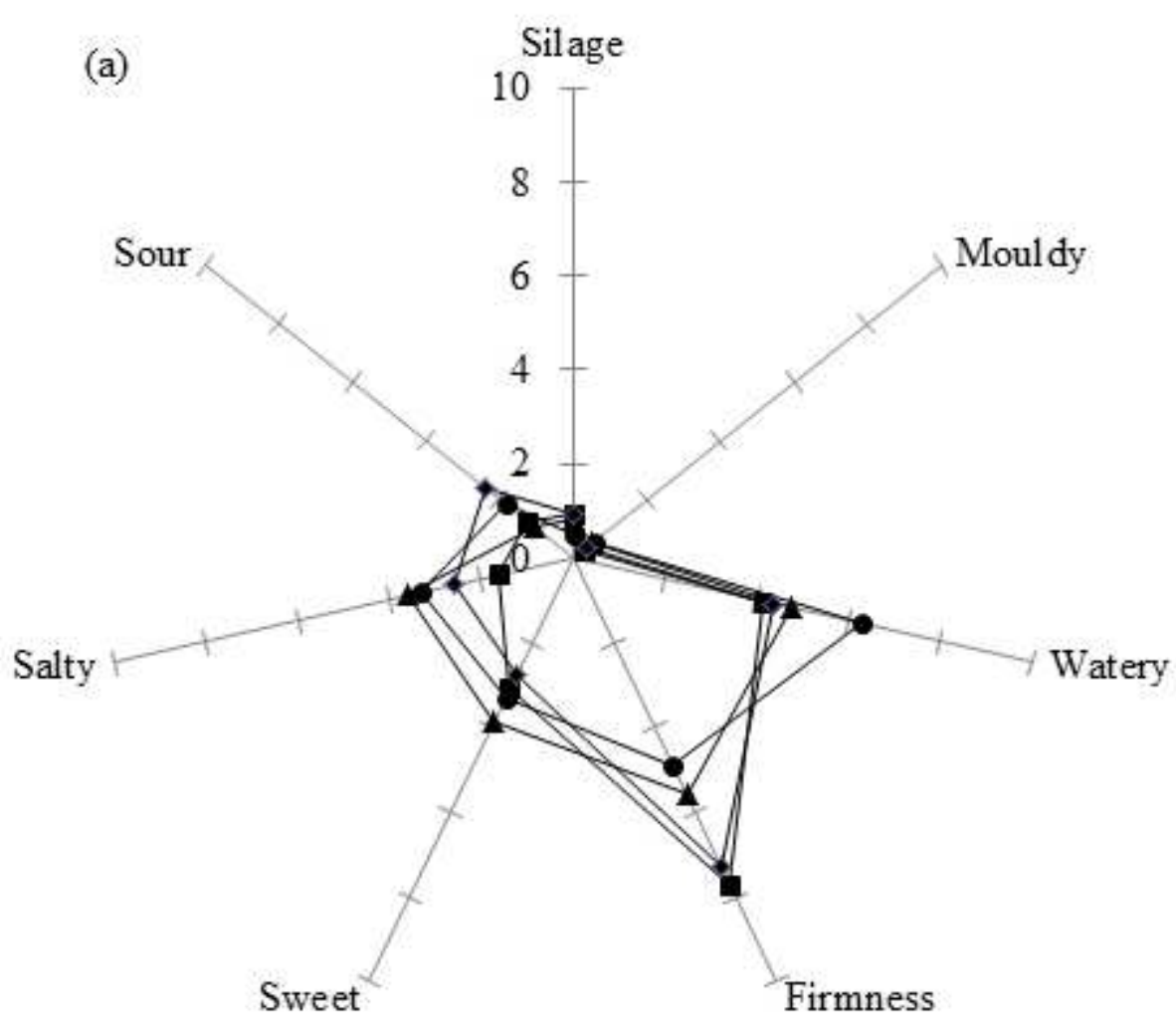




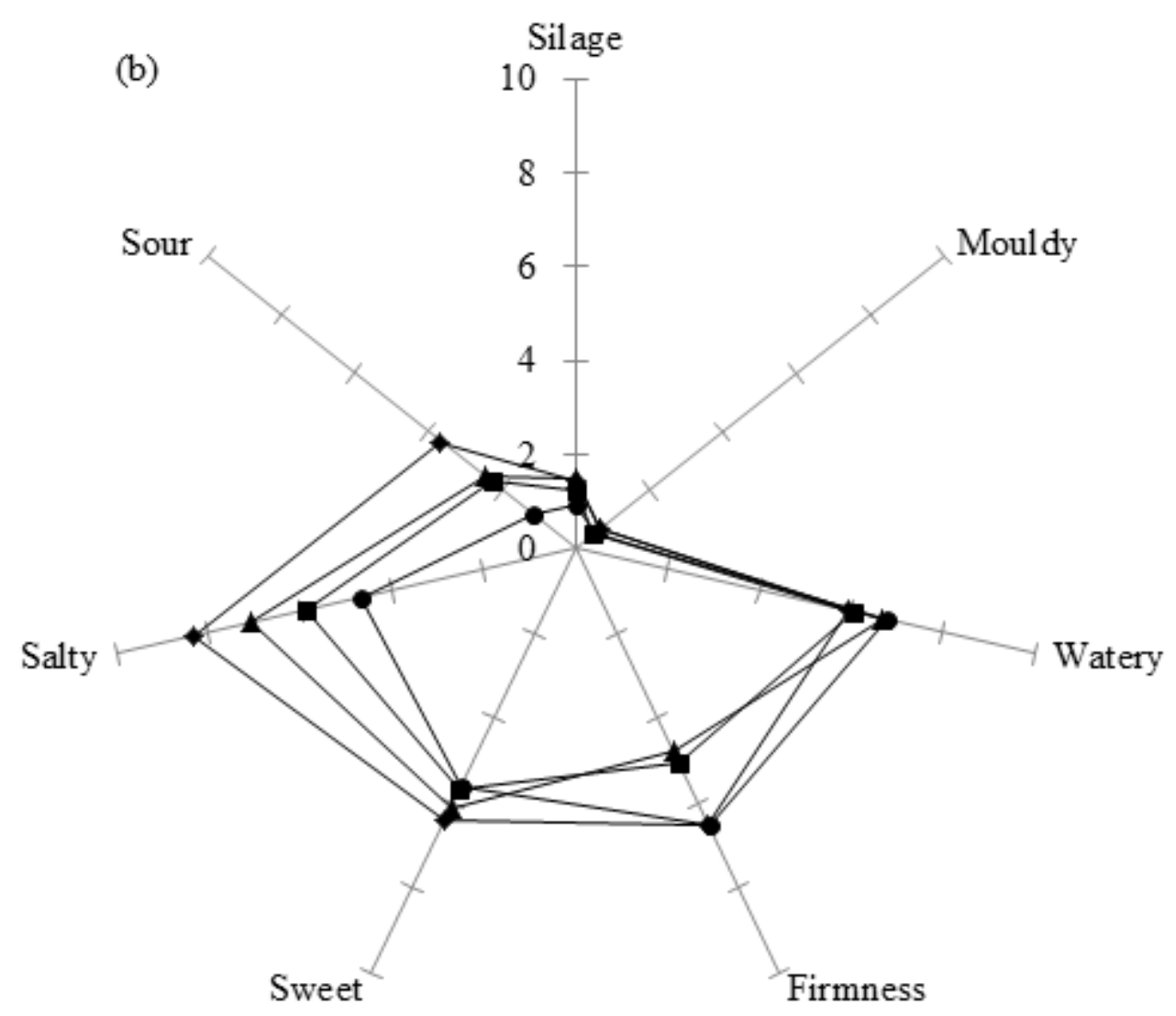




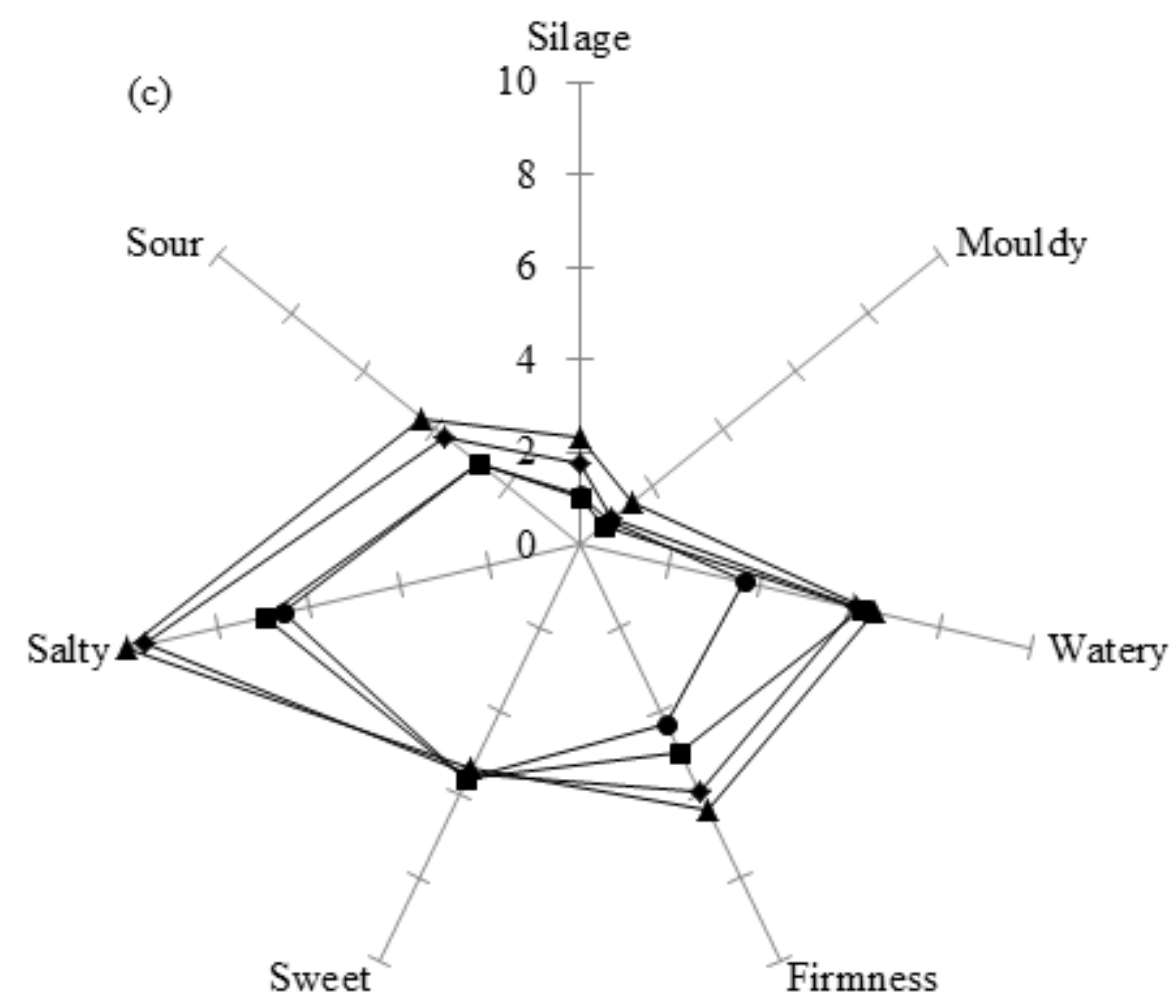

